\title{
HBV/HIV co-infection: The dynamics of HBV in South African patients with AIDS
}

\author{
Simnikiwe H Mayaphi, Theresa M Rossouw, Difuro P Masemola, Steve A S Olorunju, M Jeffrey Mphahlele, Desmond J Martin
}

Objective. As sub-Saharan Africa is highly endemic for hepatitis B virus (HBV) and human immunodeficiency virus (HIV) infections, and their co-infection requires special management, we aimed to assess the serological and molecular characteristics of HBV in patients with AIDS.

Design. This was a cross-sectional, case control study, which enrolled 200 patients with AIDS and 200 HIV-negative controls. HBV serology was done in all participants and HCV serology in participants with a hepatitis B core antibody (anti-HBc) only serological pattern. Nested HBV polymerase chain reaction (PCR) and HBV viral load assays were used for HBV molecular detection.

Results. Hepatitis B surface antigen ( $\mathrm{HBsAg}$ ) prevalence was 3-fold higher while the 'anti-HBc only' pattern was 6-fold higher in the AIDS group compared with the controls. Mean HBV viral load was significantly higher in $\mathrm{HBsAg}$-positive patients with CD4+ cell counts $<100$ cells $/ \mu$ than in patients with CD4+ cell counts of $100-200$ cells $/ \mu \mathrm{l}(p=0.019)$. There were markedly reduced hepatitis
B surface antibody (anti-HBs) titres in the AIDS group compared with the controls $(p=0.002)$. A significant proportion of AIDS patients with an 'anti-HBc only' pattern had $\mathrm{CD} 4+$ cell counts $<100$ cells $/ \mu \mathrm{l}(p=0.004)$. Occult HBV prevalence was $3.5 \%$ in the AIDS group compared with $1 \%$ in the controls $(p=0.092)$. When occult HBV infection was taken into consideration, the overall HBV prevalence became $10 \%$ in the AIDS group and $3 \%$ in the control group.

Conclusion. We showed an increased HBV prevalence in patients with AIDS and identified a CD4+ cell count $<100$ cells/ $\mu$ l as a major risk factor for the 'anti-HBc only' pattern and increased HBV replication. These data have significant public health implications for $\mathrm{HBV}$ in developing countries, especially in areas where antiretroviral (ARV) guidelines do not cater for HBV/HIV co-infection.

S Afr Med J 2012:157-162.
Approximately 2 billion people worldwide have evidence of hepatitis $B$ virus (HBV) exposure, and an estimated 400 million are chronically infected. ${ }^{1}$ Sub-Saharan Africa has the largest burden of human immunodeficiency virus (HIV) infections in the world and is also an HBV endemic area. South Africa's HBV prevalence is estimated to be $10 \%$; however, this estimate comes from studies that were conducted in high-risk groups for HBV such as adult males or children during the pre-vaccination era. ${ }^{2}$

HBV co-infection with HIV is common, affecting $5-10 \%$ of patients infected with HIV. In developed countries where sexual and injection-drug-use exposures account for most HBV and HIV infections, the prevalence of chronic HBV infection may be $\geq 10$-fold higher than the background prevalence among patients infected with HIV in some risk groups. ${ }^{3}$ Most data from sub-Saharan Africa show

Department of Medical Virology, University of Pretoria/ Tshwane Academic Division National Health Laboratory Service, Pretoria, South Africa Simnikiwe H Mayaphi, MB ChB, FC Path (SA), MMed Desmond J Martin, MB ChB, FC Path (SA), MMed

Department of Family Medicine, University of Pretoria, South Africa Theresa M Rossouw, MB ChB, M Phil - Applied Ethics, MPH

Tshwane District Hospital ARV Clinic, Pretoria, South Africa Difuro P Masemola, BSc, MB ChB

Biostatistics Unit, Medical Research Council, Pretoria, South Africa Steve A S Olorunju, BSc, MSc, PhD

Department of Virology, University of Limpopo, Medunsa campus/National Health Laboratory Service, Pretoria, South Africa

M Jeffrey Mphahlele, BSc, MSc, PhD less than 2-fold or no increase in the prevalence of chronic HBV infections in patients infected with $\mathrm{HIV}^{4}$ with few studies reporting more than a 2 -fold increase. ${ }^{5,6}$

The development of an immunosuppressive status such as in organ transplantation, cancer and HIV/AIDS might induce reactivation of occult HBV with reappearance of the typical serological profile of productive infection..$^{7-9}$ Occult $\mathrm{HBV}$ infection refers to the presence of HBV DNA without detectable hepatitis B surface antigen (HBsAg) with or without hepatitis B core antibodies (anti-HBc) or hepatitis B surface antibodies (anti-HBs) outside the pre-seroconversion window period. ${ }^{10}$ The 'anti-HBc only' serological pattern is a common marker of occult HBV infection. Some South African studies have reported a high prevalence of occult HBV infection among patients infected with HIV. ${ }^{5,11}$

The limitations (e.g. small sample size) and divergent results of the few sub-Saharan HBV/HIV co-infection studies demonstrate a need for more research in this area. ${ }^{4}$ We aimed to assess the serological and molecular characteristics of $\mathrm{HBV}$ in patients with AIDS.

\section{Methods \\ Study population}

This cross-sectional, case-control study was conducted in an urban, secondary hospital (Tshwane District Hospital, Pretoria), Gauteng province, South Africa. Four hundred South African participants (200 patients with AIDS and 200 HIV-negative participants) were enrolled from June 2007 to January 2009. AIDS was defined as CD4+ cell count of $<200$ cells/ $\mu$ in patients infected with HIV. All participants were recruited from the same centre, Tshwane District Hospital HIV Clinic, which offers both HIV testing and antiretrovirals (ARVs), e.g. if tested positive for HIV at a voluntary counselling and testing (VCT) section, patients get referred to the ARV section of the clinic. HIV-negative participants (control group) were identified and recruited after HIV testing, while participants with AIDS were recruited from the HIV clinic before starting ARV treatment. The minimum age requirement for enrollment was 
18 years. Questionnaire forms were used to collect participants' demographic and HBV risk-assessment data. Ethics approval for this study was granted by the University of Pretoria, and written informed consent was obtained from all participants before enrollment.

\section{Sample collection and laboratory tests}

Plasma and serum samples were obtained from all participants. All samples were stored at $-70^{\circ} \mathrm{C}$ within $24-72$ hours of collection.

Serological testing was done on serum samples and molecular testing on plasma samples. Architect (Abbott Diagnostics, Wiesbaden, Germany) and Modular Analytics E170 (Roche Diagnostics, Mannheim, Germany) immunoassays, which are fourth-generation HIV enzyme-linked immunosorbent assays (ELISA), were used for HIV diagnosis. Axsym immunoassays (Abbott Diagnostics, Wiesbaden, Germany) were used for HBV and hepatitis $\mathrm{C}$ virus (HCV) serological testing. The HBV screening included $\mathrm{HBsAg}$, anti-HBs and anti-HBc. Hepatitis B e-antigen (HBeAg) and hepatitis B e-antibodies (anti-HBe) were done on all HBsAg-positive specimens as well as those found to be positive for anti-HBc alone during HBV screening. HCV serology was done in participants with an 'anti-HBc only' serology as HCV infection is often associated with this serological picture. ${ }^{12}$

Viral nucleic acid was extracted from $100 \mu \mathrm{l}$ of plasma using the MagNa Pure LC Total Nucleic Acid Isolation kit in the MagNa Pure LC instrument (Roche Diagnostics, Germany) according to manufacturer's instructions. Nested HBV DNA polymerase chain reaction (PCR) assay (qualitative in-house assay) was performed to detect occult HBV infections in participants who were HBsAgnegative after HBV serological screening. HBV core primers were used for nested HBV-PCR as previously described..$^{11}$ The sensitivity of the nested HBV-PCR was determined by serial dilution (10-fold dilutions: $10^{-1}-10^{-7}$ ) of samples with known HBV viral loads.

HBV viral loads were determined by Cobas TaqMan 48 HBV assay (Roche Molecular Systems, Inc., Branchburg, USA) for all HBsAg-positive participants, those with 'anti-HBc only' pattern and in those positive on nested HBV PCR. Epics and UniCel DxC880i analysers (Beckman Coulter Diagnostics) were used for CD4 count measurements and liver function tests (LFTs), respectively.

\section{Data analysis}

Descriptive analysis was used to obtain summary statistics (mean, standard deviation, standard error, and $95 \%$ confidence intervals) for the parameters. This was followed by a comparison between the groups using two sample $t$-test for proportions. The mean HBV viral load and anti-HBs measurements between groups were compared using the Mann-Whitney or Wilcoxon rank sum test. The software used was STATA 11.2. A $p$-value of $<0.05$ was considered statistically significant.

\section{Results \\ Demographics}

Black subjects comprised $98 \%$ of participants in this study and there were more males in the control group than in the AIDS group. The mean age was higher in the AIDS group. Only a small proportion of participants were vaccinated $(0.5 \%$ in the AIDS group v. $3 \%$ in controls). Intravenous (IV) drug use and the number of lifetime sexual partners were significantly higher in the controls and the AIDS group, respectively. The mean CD4+ cell count in the AIDS group was 92.9 cells/ $\mu$ l (Table 1$)$.

\section{HBV serology results}

HBsAg prevalence of $6.5 \%$ in the AIDS group was significantly higher than that of $2 \%$ in the control group. The total HBV exposure was significantly higher in the AIDS group compared with the control group, and the same trend was also noticed for both $\mathrm{HBeAg}$ and 'anti-HBc only' prevalence (Table 1). When stratifying the HBsAgpositive AIDS participants by CD4+ cell counts, the group with $\mathrm{CD} 4+$ cell counts of $<100$ cells $/ \mu \mathrm{l}$ had a higher $\mathrm{HBeAg}$ prevalence of $83.0 \%$ (5 of 6) compared with $57.1 \%$ ( 4 of 7 ) in the group with CD4+ cell counts of $100-200$ cells/ $\mu \mathrm{l}$; however, this difference was not statistically significant $(p=0.680)$. HBeAg prevalence was $25 \%$ ( 1 of 4) in HBsAg-positive participants in the control group (Table 2). Two HBsAg-positive patients with AIDS had negative anti-HBc (Table 2).

The 'anti-HBc only' serological pattern was 6-fold higher in the AIDS group compared with the control group (Table 1). When patients with an 'anti-HBc only' serology in the AIDS group were stratified according to CD4+ cell counts, 73.7\% (14 of 19) had CD4+ cell counts of $<100$ cells $/ \mu$ l compared with $26.3 \%$ (5 of 19) in the group with CD4+ cell counts of $100-200$ cells $/ \mu \mathrm{l}$ ( $p=0.004$ ) (Table 3 ). HCV serology results were negative in all patients with an 'anti-HBc only' pattern (Table 3 ).

In the AIDS and control groups $60.5 \%$ and $76.0 \%$, respectively, had no immunity to HBV (Table 1). AIDS patients had significantly decreased anti-HBs titres; mean titre of $235.17 \mathrm{mIU} / \mathrm{ml}$ compared to $514.29 \mathrm{mIU} / \mathrm{ml}$ in the control group $(p=0.002)$. No difference was found in mean anti-HBs titres when the AIDS group was stratified by $\mathrm{CD} 4+$ cell counts.

\section{HBV viral load results}

The lower detection limit of the HBV viral load assay was 6 IU/ $\mathrm{ml}(\sim 30$ copies $/ \mathrm{ml})$. Mean HBV viral loads were significantly higher in HBsAg-positive patients with CD4+ cell counts of $<100$ cells/ $\mu$ l compared with the group with CD4+ cell counts of 100 200 cells $/ \mu \mathrm{l}(p=0.019)$ (Table 2$)$. HBV viral load values $>110000$ $000 \mathrm{IU} / \mathrm{ml}$ were excluded from the comparison between these groups as they are outliers (fall outside the reference range). Interestingly, even the $\mathrm{HBeAg}$-negative (but anti-HBe-positive) patient (3 658) with a CD4+ cell count of $<100$ cells/ $\mu$ l (Table 2) had a very high HBV viral load compared with counterparts (3 464 and 3 321) with CD4+ cell counts of $100-200$ cells/ $\mu$ l.

\section{Nested HBV-PCR results}

Nested HBV-PCR was used for detection of occult HBV infection, and its performance was assessed in all HBsAg-positive samples; it was positive in all these samples except for one that had a $<6 \mathrm{IU} / \mathrm{ml}$ viral load (with an HBsAg titre of 217.04 S/N) (Table 2). Its lower detection limit was $0.2 \mathrm{IU} / \mu \mathrm{l}(\sim 1 \mathrm{copy} / \mu \mathrm{l})$ on serial dilution of HBsAg-positive samples with known viral loads (Fig. 1). This high sensitivity of nested HBV-PCR was noticed in some samples where HBV viral load was $<6 \mathrm{IU} / \mathrm{ml}$, but nested PCR was clearly positive (Table 3 ). Occult HBV infection was detected in most participants with 'anti-HBc only' serological picture (Table 3 ) and in one participant who was positive for both anti-HBc and anti-HBs (confirmed on repeat serology). The latter had an anti-HBs titre of $15 \mathrm{mIU} / \mathrm{ml}$, a CD4+ cell count of 72 cells $/ \mu$, positive nested HBV-PCR, HBV viral load of $290 \mathrm{IU} / \mathrm{ml}$, and alanine aminotransferase (ALT) of $16 \mathrm{IU} / \mathrm{l}$. In total, occult HBV prevalence was $3.5 \%$ in the AIDS group compared with $1 \%$ in the control group ( $p$-value - 0.092). Only one patient with occult HBV infection had an HBV viral load of $>200 \mathrm{IU} / \mathrm{ml}$ (mentioned above). Contamination was successfully avoided in the nested PCR runs as all negative controls used at the end of each run or in between 
Table 1. Demographics and HBV serology data

\begin{tabular}{|c|c|c|c|}
\hline & $\begin{array}{l}\text { AIDS group } \\
(n=200)\end{array}$ & $\begin{array}{l}\text { Control group } \\
(n=200)\end{array}$ & $p$-values \\
\hline \multicolumn{4}{|l|}{ Demographics } \\
\hline Mean age (range) & $37(22-75)$ & $31(18-71)$ & 0.000 \\
\hline Mean CD4 count (range) & $92.9(1-199)$ & ND & N/A \\
\hline \multicolumn{4}{|l|}{ Gender } \\
\hline Males & $36.0 \%(72)$ & $52.5 \%(105)$ & 0.001 \\
\hline Females & $64.0 \%(128)$ & $47.5 \%(95)$ & 0.001 \\
\hline \multicolumn{4}{|l|}{ Race } \\
\hline Blacks & $99.5 \%(199)$ & $97.0 \%(194)$ & 0.057 \\
\hline Whites & $0.5 \%(1)$ & $3.0 \%(6)$ & 0.057 \\
\hline Intravenous drug use ${ }^{*}$ & $0.0 \%(0$ in 200$)$ & $4.6 \%(9$ in 197$)$ & 0.002 \\
\hline MSM * & $4.3 \%(3$ in 70$)$ & $1.0 \%(1$ in 104$)$ & 0.548 \\
\hline \multicolumn{4}{|l|}{ Lifetime sexual partners* } \\
\hline$<5$ & $46.2 \%(73)$ & $57.5 \%(92)$ & 0.044 \\
\hline$\geq 5$ & $53.8 \%(85)$ & $42.5 \%(68)$ & 0.044 \\
\hline \multicolumn{4}{|c|}{$\begin{array}{l}\text { Residence within the first } 5 \text { years } \\
\text { of life* }\end{array}$} \\
\hline Rural & $65.3 \%(130)$ & $68.0 \%(134)$ & 0.569 \\
\hline Urban & $34.7 \%(69)$ & $32.0 \%(63)$ & 0.569 \\
\hline HBV vaccination & $0.5 \%$ & $3.0 \%$ & 0.057 \\
\hline \multicolumn{4}{|l|}{ HBV serology } \\
\hline $\mathrm{HBsAg}$ & $6.5 \%(13)$ & $2 \%(4)$ & 0.026 \\
\hline $\mathrm{HBeAg}$ & $4.5 \%(9)$ & $0.5 \%(1)$ & 0.010 \\
\hline Anti-HBc only & $9.5 \%(19)$ & $1.5 \%(3)$ & 0.000 \\
\hline Anti-HBs only & $3 \%(6)$ & $2.5 \%(5)$ & 0.760 \\
\hline Anti-HBs + anti-HBc & $18.5 \%(37)$ & $17 \%(34)$ & 0.695 \\
\hline Anti-HBc + anti-HBe & $2 \%(4)$ & $1 \%(2)$ & 0.411 \\
\hline Negative HBV markers & $60.5 \%(121)$ & $76 \%(152)$ & 0.001 \\
\hline Total HBV exposure & $36.5 \%(73)$ & $21.5 \%(43)$ & 0.001 \\
\hline
\end{tabular}

samples were negative (e.g. Fig. 1). Subsequently, all positive samples on nested PCR were sequenced, and the phylogenetic tree also did not show any indication of contamination (data not shown). When occult HBV infection was taken into consideration, the overall HBV prevalence in this study became $10 \%$ in the AIDS group and $3 \%$ in the control group.

\section{Liver function tests}

ALT levels were normal or slightly raised in HBsAg-positive patients with AIDS (Table 2).

\section{Discussion}

This study demonstrates a 3-fold increase in HBsAg prevalence in patients with AIDS (6.5\%) compared with the control group (2\%). This impact would have been difficult to observe without using a control group, as the average South African HBsAg prevalence is considered to be $10 \%$. Therefore, HBV/HIV co-infection studies without a control group are more likely to underestimate the impact HIV/AIDS has on HBV prevalence, especially in areas of high HBV endemicity where most of the population are exposed to HBV during childhood. A study in South African patients with AIDS at the Chris Hani Baragwanath Hospital noted a similar HBsAg prevalence of $6 \%$ but could not conclude whether this was high or not, probably because of the lack of a control group. ${ }^{13}$ The reason for low HBV prevalence $(<10 \%)$ in both groups of this study could be that the HBsAg prevalence of $10 \%$ comes from studies conducted in populations at high risk for chronic HBV (adult males or children only) and, therefore, is not always applicable for assessment of HBV prevalence in the general adult population. For instance, Tsebe et al. ${ }^{14}$ noticed a $3.3 \%$ HBsAg prevalence in the general adult population of Limpopo (formerly Northern Province). Despite the number of lifetime sexual partners being significantly higher in the AIDS group, this is unlikely to have influenced the high HBV prevalence in this group as other HBV risk factors such as male gender and IV drug use were significantly higher in the controls. 
Table 2. Characteristics of HBsAg-positive individuals in the AIDS group v. control group

\begin{tabular}{|c|c|c|c|c|c|c|c|c|c|c|c|}
\hline 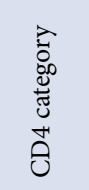 & $\stackrel{\theta}{\Xi}$ & $\begin{array}{l}\overrightarrow{0} \\
\overrightarrow{0} \\
\overline{0} \\
0\end{array}$ & $\begin{array}{l}\sum_{\infty}^{\infty} \\
0 \\
0 \\
\text { 工ు }\end{array}$ & 章 & 岂 & $\begin{array}{l}\sum_{j}^{\infty} \\
0 \\
0\end{array}$ & 童 & 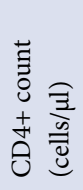 & 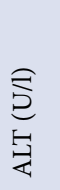 & 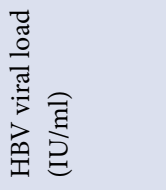 & 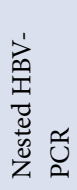 \\
\hline \multicolumn{12}{|c|}{ AIDS group } \\
\hline \multirow{6}{*}{ 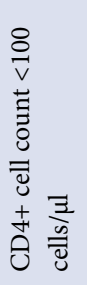 } & 3354 & F & + & - & + & + & - & 2 & 31 & 33839284 & + \\
\hline & 3658 & M & + & - & + & - & + & 20 & 29 & 17532020 & + \\
\hline & 3261 & M & + & - & + & + & - & 37 & 42 & $>110000000$ & + \\
\hline & 2950 & M & + & - & - & + & - & 71 & 18 & 1560496 & + \\
\hline & 3274 & F & + & - & + & + & - & 93 & 60 & 10547142 & + \\
\hline & 4070 & M & + & - & + & + & - & 20 & 46 & $>110000000$ & + \\
\hline \multirow{12}{*}{ 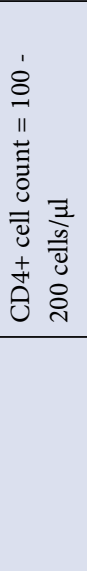 } & 3791 & M & + & - & + & + & - & 122 & 58 & $>110000000$ & + \\
\hline & 3464 & M & + & - & + & - & + & 140 & 26 & 278 & + \\
\hline & 3321 & M & + & - & + & - & + & 149 & 56 & 60221 & + \\
\hline & 3269 & F & + & - & + & - & - & 183 & 21 & 95 & + \\
\hline & 4312 & $\mathrm{~F}$ & + & - & + & + & - & 160 & 61 & 6760000 & + \\
\hline & 3869 & M & + & - & - & + & - & 142 & 50 & 97654 & + \\
\hline & 3975 & $\mathrm{~F}$ & + & - & + & + & - & 102 & 19 & 234369 & + \\
\hline & \multicolumn{11}{|c|}{ Control group (HIV-negative) } \\
\hline & N005 & M & + & - & + & - & + & ND & ND & 2340 & + \\
\hline & N011 & M & + & - & + & + & - & ND & ND & $>110000000$ & + \\
\hline & N029 & $\mathrm{F}$ & + & - & + & - & + & ND & ND & $<6$ & - \\
\hline & N060 & $\mathrm{F}$ & + & - & + & - & + & ND & ND & 157 & + \\
\hline
\end{tabular}

Pt ID = participant identity; $\mathrm{HBsAg}=$ hepatitis B surface antigen; anti-HBs = hepatitis B surface antibody; anti- $\mathrm{HBc}=$ hepatitis B core antibody; $\mathrm{HBeAg}=$ hepatitis B virus e antigen; anti-HBe = antibody to $\mathrm{HBV}$ antigen; $\mathrm{ALT}=$ alanine aminotransferase; $\mathrm{HBV}-\mathrm{PCR}=\mathrm{HBV}$ polymerase chain reaction; $\mathrm{F}=$ female; $\mathrm{M}=\mathrm{male} ; \mathrm{ND}=$ not done.

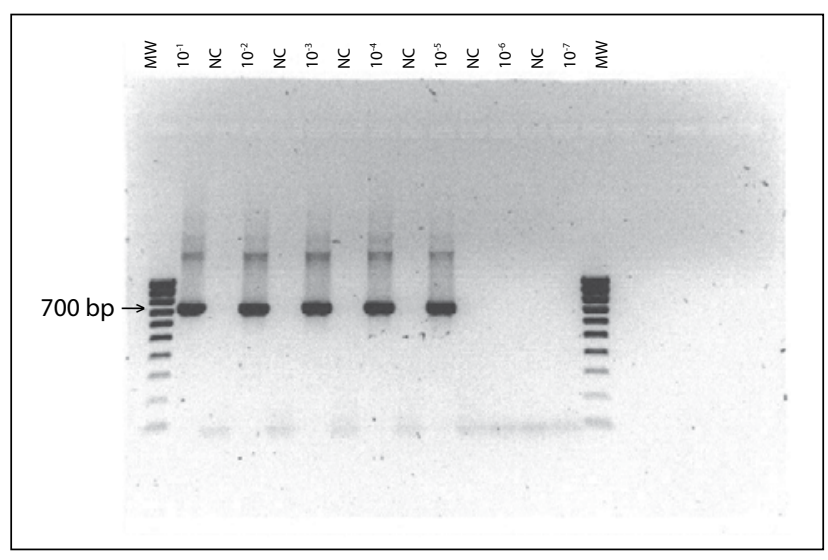

Fig. 1. Serial dilution of a sample that had an $\mathrm{HBV}$ viral load of $33839.3 \mathrm{IU} /$ $\mu l$. Nuclease-free water served as a template for negative controls (NC) used between dilutions. Analysis of nested HBV-DNA PCR products was done on $2 \%$ agarose gel electrophoresis. Molecular weight $(\mathrm{MW})$ marker $=100 \mathrm{bp}$ DNA marker.

HBV prevalence varies considerably in South Africa owing to gender, age, race and geographic location of a studied population, e.g. blacks, males, and residence in the rural or coastal areas such as Eastern Cape and KwaZulu-Natal (KZN) are risk factors associated with high HBV prevalence. This prevalence could be as high as $10 \%$ or more in those at high risk for $\mathrm{HBV}$ and as low as $1 \%$ in low risk groups as noted in children born into an urban environment. ${ }^{2}$ There was a lower HBV prevalence in the control group despite more risk factors for chronic HBV prevalence such as higher number of males and IV drug users (Table 1). South African studies have also shown an increased HBV prevalence in adult patients infected with HIV; ${ }^{5,6}$ one reported a $22.9 \%$ and the other a $5 \% \mathrm{HBsAg}$ prevalence. However, the latter study used an HBsAg prevalence of $1 \%$ as a reference point even though this prevalence rate was only noticed among a group of children born in an urban area, and would therefore be inappropriate for a diverse adult population in terms of risk factors for HBV.

Mean HBV viral load of HBsAg-positive patients was significantly higher in the AIDS group with CD4+ cell counts of $<100$ cells $/ \mu$ l, indicating an increased HBV replication with profound immunosuppression. This in turn results in an increased risk of HBV transmission to patients' close contacts (e.g. family members and friends) and susceptible health care workers. Immunosuppression could also account for a very high HBV viral load in an $\mathrm{HBeAg-negative} \mathrm{(but} \mathrm{anti-HBe-}$ positive) patient with a CD4+ cell count of $<100$ cells $/ \mu 1,{ }^{15}$ and for failure of some HBsAg-positive patients to produce anti$\mathrm{HBc}$ (Table 2). ${ }^{16}$ The undetectable HBV DNA in an HBsAgpositive participant in the control group was surprising; however, this phenomenon has been described in chronic HBV infection especially after HBeAg seroclearance. ${ }^{17}$

Liver damage is mediated by cytotoxic immune responses in immunocompetent individuals. However, HBV/HIV co-infected 
Table 3. Characteristics of patients with 'anti-HBc only' serological pattern in the AIDS group versus control group

\begin{tabular}{|c|c|c|c|c|c|c|c|c|}
\hline 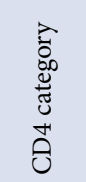 & 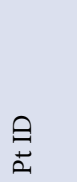 & $\underset{4}{\circ}$ & 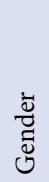 & 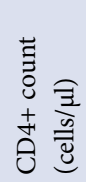 & 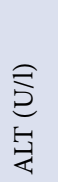 & $\begin{array}{l}\overrightarrow{0} \\
0 \\
0 \\
0 \\
0 \\
0 \\
ن \\
0 \\
0\end{array}$ & 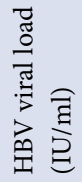 & 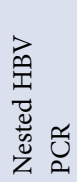 \\
\hline \multirow{15}{*}{ 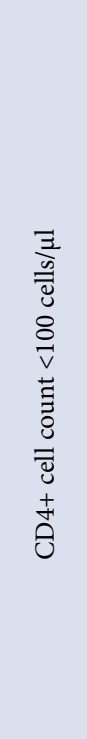 } & \multicolumn{8}{|c|}{ AIDS group } \\
\hline & 3267 & 26 & $\mathrm{~F}$ & 6 & 13 & $\mathrm{ND}^{*}$ & TND & - \\
\hline & 3319 & 32 & $\mathrm{~F}$ & 21 & 35 & - & 127 & + \\
\hline & 3344 & 35 & $\mathrm{~F}$ & 79 & 17 & - & $<6$ & - \\
\hline & 3366 & 34 & $\mathrm{~F}$ & 27 & 23 & - & $<6$ & - \\
\hline & T33 & 48 & $\mathrm{M}$ & 87 & 57 & - & $<6$ & + \\
\hline & 3590 & 57 & M & 44 & 16 & - & TND & - \\
\hline & 3668 & 39 & $\mathrm{~F}$ & 61 & 17 & - & $<6$ & - \\
\hline & 3712 & 31 & $\mathrm{~F}$ & 2 & 41 & - & $<6$ & - \\
\hline & 3734 & 39 & M & 20 & 49 & - & 36 & + \\
\hline & 3749 & 29 & $\mathrm{~F}$ & 20 & 44 & - & TND & - \\
\hline & 3811 & 57 & $\mathrm{~F}$ & 69 & 19 & - & TND & - \\
\hline & 3832 & 37 & M & 80 & 41 & - & 126 & + \\
\hline & 4096 & 28 & $\mathrm{~F}$ & 94 & 14 & - & $<6$ & - \\
\hline & 4302 & 45 & $\mathrm{~F}$ & 14 & 17 & & TND & - \\
\hline \multirow{9}{*}{ 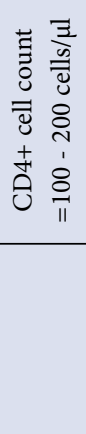 } & 3671 & 31 & $\mathrm{~F}$ & 185 & 51 & - & 44 & + \\
\hline & 3772 & 33 & $\mathrm{~F}$ & 103 & 28 & - & $<6$ & - \\
\hline & 3812 & 50 & $\mathrm{M}$ & 164 & 30 & - & $<6$ & + \\
\hline & 3916 & 24 & $\mathrm{~F}$ & 180 & 51 & - & TND & - \\
\hline & 8104 & 26 & $\mathrm{~F}$ & 144 & 40 & - & $<6$ & - \\
\hline & \multicolumn{8}{|c|}{ Control group (HIV-negative) } \\
\hline & N012 & 29 & M & ND & ND & - & $<6$ & + \\
\hline & N068 & 28 & M & ND & ND & - & $<6$ & - \\
\hline & N199 & 39 & M & ND & ND & - & 99 & + \\
\hline
\end{tabular}

Pt ID = participant identity; $\mathrm{ALT}=$ alanine aminotransferase; $\mathrm{HCV}=$ hepatitis $\mathrm{C}$ virus; $\mathrm{HBV}=$ hepatitis $\mathrm{B}$ virus; $\mathrm{HBV}-\mathrm{PCR}=\mathrm{HBV}$ polymerase chain reaction; $\mathrm{F}=$ female, $\mathrm{M}=$ male; $\mathrm{ND}=$ not done; TND = target not detected; ${ }^{*}$ Insufficient sample.

patients are often asymptomatic and usually have normal or slightly raised ALT levels (Table 2), possibly because of weak cytotoxic immune responses as a result of immunosuppression. Paradoxically, the risk of developing cirrhosis is much greater in HBV/HIV co-infected patients despite having less necro-inflammatory activity in the liver. HBV replication in the liver is non-cytopathic; however, fibrosing cholestatic hepatitis, a severe and rapidly progressive form of HBV infection thought to be due to a direct cytopathic effect of the virus, has been anecdotally described in patients infected with HIV and other groups of immunosuppressed patients. ${ }^{18} \mathrm{HBV} /$ HIV co-infected patients with AIDS are also at a high risk of developing immune reconstitution inflammatory syndrome (IRIS) after initiation of highly active antiretroviral therapy (HAART). The accelerated HBV progression (Table 2) and higher likelihood of IRIS in patients with AIDS clearly argue for earlier initiation of HAART in HBV co-infected patients before their CD4+ cell counts drop below $200 \mathrm{cells} / \mu \mathrm{l}$ as advocated by the $2010 \mathrm{WHO}$ ARV guidelines. ${ }^{19}$

$\mathrm{HBV} / \mathrm{HIV}$ co-infection requires special management as some ARV drugs (tenofovir, lamivudine and emtricitabine) are active against HBV. Dual therapy for HBV is recommended in HIV co-infected patients in order to avoid HBV drug resistance, particularly to lamivudine, which has a low resistance barrier. As a result, the use of tenofovir and lamivudine/emtricitabine is recommended as part of a HAART regimen for HBV/HIV co-infected patients. ${ }^{20}$

Isolated anti-HBc is commonly associated with occult HBV infection. Mphahlele et al. ${ }^{11}$ reported an occult HBV prevalence of $33.3 \%$ in South Africans infected with HIV who had an 'anti-HBc only' serological picture. In our study, there was a significantly high proportion of patients with an 'anti-HBc only' serological picture in the AIDS group, and occult HBV infection was detected in $31.6 \%$ of these patients. The finding of positive nested HBV PCR in some samples with $\mathrm{HBV}$ viral load $<6 \mathrm{IU} / \mathrm{ml}$ shows that a more sensitive test is needed for the diagnosis of occult HBV (Table 3). Other South African studies have also reported a high prevalence of occult HBV in patients with AIDS. ${ }^{5,6,11}$ The finding of negative HCV serology in all patients with an 'anti-HBc only' serological picture was not surprising, given that South Africa has an HCV prevalence of less than $2 \% .{ }^{21}$

Although there is uncertainty regarding the clinical significance of occult HBV infection, a clear association of occult HBV infection and 
liver disease in the absence of other causes such as HCV infection or alcohol abuse has been described. ${ }^{10}$ The prevalence of occult HBV ranges from $0 \%$ to $10 \%$ among individuals without liver disease, $11 \%$ to $19 \%$ in patients with chronic hepatitis, $12 \%$ to $61 \%$ in patients with hepatocellular carcinoma, and $1 \%$ to $95 \%$ in patients with $\mathrm{HCV}$ infection..$^{22}$ It would be difficult to diagnose occult HBV infection in patients with AIDS as some guidelines utilise only HBsAg for HBV screening. ${ }^{19,23}$ More data are needed on occult HBV infection to elucidate its role in clinical disease in HIV co-infected patients, especially in areas of high HBV endemicity.

Markedly reduced anti-HBs titres could explain the high HBsAg prevalence and 'anti-HBc only' presentation in patients with AIDS, as some of these individuals eventually lose protective antibodies. This loss of HBV protective immunity may lead to reactivation of HBV, or exposure to new HBV infections. As patients infected with HIV lose protective antibody levels more quickly ( $40 \%$ loss in 1 year vs $5 \%$ loss in HIV-negative individuals), ${ }^{24,25}$ it may be a good practice to administer $\mathrm{HBV}$ vaccine booster doses to those with relatively low anti-HBs titres prior to commencement of HAART. Some experts use anti-HBs levels of less than $100 \mathrm{IU} / \mathrm{l}$ as a cut-off point for $\mathrm{HBV}$ vaccine booster doses in HIV-infected individuals, ${ }^{26}$ and our findings support this practice and reinforce its value in HIV endemic countries. The lack of HBV immunity in $60.5 \%$ of patients with AIDS could be explained by the fact that HBV vaccine was only implemented in the South African Expanded Programme on Immunisation (EPI) in 1995 and then not routinely offered to adults. Patients infected with HIV but with no $\mathrm{HBV}$ immunity should be considered for HBV vaccination to prevent HBV co-infection. Hepatitis B vaccine response in patients infected with HIV correlates with the CD4+ cell counts $(87 \%, 33 \%$ and $25 \%$ in CD4 count $>500,200-500$ and $<200$ cells/ $\mu \mathrm{l}$, respectively). ${ }^{24}$ Therefore, HBV vaccination of patients infected with HIV may be most costeffective in patients with CD4 count $>500$ cells/ $/ \mu$. In addition to using HBsAg in the HBV screening protocol, HIV management guidelines for developing countries should also incorporate anti-HBs to identify patients with low or no HBV immunity.

HIV/AIDS increased HBV prevalence and has enhanced other transmission risk patterns for HBV, which were previously uncommon in sub-Saharan Africa. For instance, horizontal transmission in childhood predominates in this region, but, with high HBV viral loads in HIV co-infected patients, there is now a high risk for both horizontal transmission among adults and vertical transmission of HBV. This undermines the HBV vaccination efforts which are targeted at reducing the HBV prevalence, and warrants changes in HBV screening and vaccination policies in sub-Saharan Africa in order to curb the spread of HBV. For example, in the past HBV screening of pregnant South African women was not considered to be cost-effective as HBV mono-infected carriers in South Africa are usually $\mathrm{HBeAg}$-negative and therefore less infectious. ${ }^{27}$ This practice may need to be changed for HIV/HBV co-infected patients with AIDS as they tend to be HBeAg-positive with high HBV viral loads.

\section{Conclusions}

This study demonstrated a significantly increased HBV prevalence and decreased anti-HBs titres in patients with AIDS, and also identified a CD4+ cell count of $<100$ cells $/ \mu l$ as a major risk factor for the 'anti-HBc only' serological pattern and increased HBV replication. There was an increased prevalence of occult HBV infection in patients with AIDS. These findings have important diagnostic and treatment implications for HBV in patients with AIDS, especially in areas with a high burden of HIV and HBV infections. Therefore, a more comprehensive HBV screening programme is recommended for adequate management of HBV in HIV/AIDS. This should include HBsAg and anti-HBs, to identify HBsAg-positive individuals and also those with no HBV immunity or low anti-HBs titres. Although this comprehensive HBV screening has cost implications, it could be cost-effective even in resource-constrained settings when HBV vaccine is made available for prevention of $\mathrm{HBV}$ in patients infected with HIV. Early initiation of HAART should be considered in HBV/ HIV co-infection to avoid HBV disease progression and IRIS, which are more likely to occur at low CD4+ cell counts.

The limitations of this study include the small sample size, and the inability to exclude other factors associated with isolated anti-HBc such as the 'HBsAg window period' of acute HBV infection.

Acknowledgements. We are grateful to the research laboratory staff of the Departments of Medical Virology (University of Pretoria) and Virology (University of Limpopo, Medunsa campus), and study sponsors for their support. Funding was received from the National Health Laboratory Service (NHLS) and Poliomyelitis Research Foundation (PRF).

\section{References}

1. Ocama P, Opio CK, Lee WM. Hepatitis B virus infection: current status. Am J Med 2005;118:1413. e15-1413.e22.

2. Kew MC. Hepatitis B virus infection: the burden of disease in South Africa. South African Journal of Epidemiology and Infection 2002;17(3\&4):4-7.

3. Alter MJ. Epidemiology of viral hepatitis and HIV co-infection. J Hepatol 2006;44:S6-S9.

4. Burnett RJ, Francois G, Kew MC, et al. Hepatitis B virus and human immunodeficiency virus coinfection in sub-Saharan Africa: a call for further investigation. Liver Int 2005;25:201.

5. Lukhwareni A, Burnett RJ, Selabe G, Mzileni MO, Mphahlele MJ. Increased detection of HBV DNA in HBsAg-positive and HBsAg-negative South African HIV/AIDS patients enrolling for highly active antiretroviral therapy at a tertiary hospital. J Med Virol 2009;81:406-412.

6. Firnhaber C, Reyneke A, Schulze D, et al. The prevalence of hepatitis B co-infection in a South African 6. Firnhaber C, Reyneke A, Schulze D, et al. The prevalence of hept
urban government HIV clinic. S Afr Med J 2008;98:541-544.

urban government HIV clinic. S Afr Med J 2008;98:541-544.
7. Raimondo G, Pollicino T, Squadrito G. What is the clinical impact of occult hepatitis B virus infection? Raimondo G, Pollicino T, Squadrit

8. Onozawa M, Hashino S, Izumiyama $K$, et al. Progressive disappearance of anti-hepatitis B surface antigen antibody and reverse seroconversion after allogeneic hematopoietic stem cell transplantation antigen antibody and reverse seroconversion after allogeneic hematopoietic stem cell trits
in patients with previous hepatitis B virus infection. Transplantation 2005;79:616-619.

9. Awerkiew S, Däumer M, Reiser M, et al. Reactivation of an occult hepatitis B virus escape mutant in an anti-HBs positive, anti-HBc negative lymphoma patient. J Clin Virol 2007;38:83-86.

10. Allain J. Occult hepatitis B virus infection. Transfus Clin Biol 2004;11:18-25.

11. Mphahlele MJ, Lukhwareni A, Burnett RJ, Moropeng LM, Ngobeni JM. High risk of occult hepatitis B virus infection in HIV-positive patients from South Africa. J Clin Virol 2006;35:14-20.

2. Hu K. Occult hepatitis B virus infection and its clinical implications. J Viral Hepatitis 2002;9:243-257.

13. Lodenyo H, Schoub B, Ally R, Kairu S, Segal I. Hepatitis B and C virus infections and liver function in AIDS patients at Chris Hani Baragwanath Hospital, Johannesburg. East Afr Med J 2000;77:13-15.

14. Tsebe KV, Burnett RJ, Hlungwani NP, Sibara MM, Venter PA, Mphahlele MI. The first five years of universal hepatitis B vaccination in South Africa: evidence for elimination of $\mathrm{HBs} A \mathrm{~g}$ carriage in under 5-year olds. Vaccine 2001;19:3919-3926.

15. Cooley L, Sasadeusz J. Clinical and virological aspects of hepatitis B co-infection in individuals Cooley L, Sasadeusz J. Clinical and virological aspects of hepatitis B co-infectio
infected with human immunodeficiency virus type-1. J Clin Virol 2003;26:185-193.

16. Avettand-Fenoel V, Thabut D, Katlama C, Poynard T, Thibault V. Immune suppression as the etiology of failure to detect anti- $\mathrm{HBC}$ antibodies in patients with chronic hepatitis B virus infection. J Clin Microbiol 2006;44:2250-2253

17. Chen C-J, Yang H-I, Jen C-L, Su J, Iloeje UH. Incidence and determinants of spontaneous decline of HBV DNA to undetectable level in patients with high viral load. J Hepatol 2010;52:S1-S21.

18. Puoti M, Torti C, Bruno R, Filice G, Carosi G. Natural history of chronic hepatitis B in co-infected patients. J Hepatol 2006;44:S65-S70.

19. World Health Organization. Antiretroviral therapy for HIV infection in adults and adolescents recommendations for a public health approach. 2010 www.who.org (accessed 12 November 2010).

20. Bhattacharya D, Thio CL. Review of hepatitis B therapeutics. Clin Infect Dis 2010;51(10):1201-1208.

21. Botha JF, Kassianides C, Schneider HR, Song E, Spearman W, van der Merwe SW. South African hepatitis C management guidelines 2010. The South African Gastroenterology Review 2010;April:20-25.

22. Chen C. Time-dependent events in natural history of occult hepatitis B virus infection: the importance of population-based long-term follow-up study with repeated measurements. J Hepatol 2005:42:438-440.

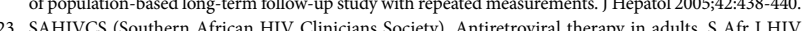
Med 2008;29:18-31.

4. Brook G. Prevention of viral hepatitis in HIV co-infection. J Hepatol 2006;44:S104-S107.

25. Laurence JC. Hepatitis A and B immunizations of individuals infected with human immunodeficiency virus. Am J Med 2005;118(10A):75S-83S.26.

26. Wasmuth J, Rockstroh J. HIV and HBV/HCV coinfections. In: Hoffmann C, Rockstroh JK, Kamps BS, eds. HIV Medicine. 15th ed. Paris: Flying Publisher, 2007:539-565.

27. Guidozzi F, Schoub BD, Johnson S, Song E. Should pregnant urban South African women be screened for hepatitis B? S Afr Med J 1993;83:103-105.

Accepted 1 November 2011 